\title{
WHY THEY STAYED: NEAR-PERFECT RETENTION IN AN ONLINE CERTIFICATION PROGRAM IN LIBRARY MEDIA
}

\author{
Dr. Katrina A. Meyer \\ The University of Memphis \\ Dr. Janis Bruwelheide \\ Montana State University \\ Russell Poulin \\ Western Cooperative for Educational Telecommunications
}

\begin{abstract}
This paper focuses on an assessment of an online certification program in K-12 library media which has a near-perfect record of retaining students. Students and graduates of the program were asked to identify reasons for enrolling (and staying enrolled) in the program as well as functions that faculty performed well. These reasons were drawn upon three theoretical models of student retention: Tinto [6], Bean and Metzner [7], the Community of Inquiry Model [8, 23, 24, 25], plus advantages of online programs. Openended questions and Likert-style items provide some support for the academic integration portion of Tinto's retention model, Bean and Metzner's retention model for adult non-traditional students, and the importance of the program being available online in explaining why students stayed. Open-ended questions and Likert-style items also support the use of the Community of Inquiry model as a way of identifying what faculty did well in the program and perhaps contributed to the students' willingness to stay enrolled in the program.
\end{abstract}

\section{KEYWORDS}

Retention, Attrition, Tinto, Bean and Metzner, Community of Inquiry, Online Learning, Teaching Presence, Social Presence, Certificate Programs

\section{INTRODUCTION}

\section{A. Purpose}

This paper will explore why 60 of 62 students enrolled in and either completed or remain enrolled in a 21credit or seven-course online certification program in library media offered by Montana State UniversityBozeman (MSU). The program, originally developed as part of a Learning Anytime, Anywhere Partnership (LAAP) grant, offered its first course in Fall term, 2001 and since that time, only two students have dropped out of the certification program due to job changes and family financial concerns. This success was intriguing to the funding agency as well as the program personnel, and thus an in-depth evaluation of the reasons for this near-perfect record of retaining students was undertaken.

One of the early criticisms of distance education was its poor record with retaining students. As practices improved and greater use was made of the Internet as well as more advanced instructional design, 
retention has improved. Some attrition is normal, of course, but how much? Brigham [1] found 66\% of distance-learning institutions had an $80 \%$ or better completion rate for their distance-learning courses; $87 \%$ of these institutions had a $70 \%$ or better completion rate. Carr [2] found great variation in coursecompletion rates of distance education students, ranging from $80 \%$ down to $50 \%$ in some instances. In contrast, Jung and Leem (in [3]) found that an online course had a higher completion rate (93.1\%) than a traditional, text-and-television, distance education course (55.25\%) and Roach [4] also found higher retention rates in online programs. Twigg's [5] projects on course redesign focused on improving course retention over traditional versions of the same course. These projects improved "drop-failure-withdrawal" (DFW) rates from $28 \%$ to $19 \%$ in an introductory psychology course at the University of Southern Maine, from $49 \%$ to $38 \%$ in a computer programming course at Drexel University, from $45 \%$ to $11 \%$ in a fine arts course at Florida Gulf Coast University, from 39\% to 25\% in an introductory sociology course at Indiana University-Purdue University Indianapolis. Given such variation in experience with retention rates, it remains important to ask what keeps online students enrolled?

This study will not be able to compare findings from an online program to a traditionally delivered program, nor can one compare the results to reasons why students may drop out of an online program. But it does assess the extent to which various theories of retention can be applied to this special group of adult students with near-perfect retention in an online certification program.

\section{LITERATURE}

\section{A. Introduction}

Three theories of student retention are pertinent to this research. And while there are additional theories, these three were chosen because Tinto has specifically focused on reasons for student attrition [6], Bean and Metzner focused on adult learners [7], and the Community of Inquiry [8, 23, 24, 25] focused on online learning. This last theory has not, to the authors' knowledge, been applied to retention, but makes sense that it could be pertinent to retention for reasons to be discussed later. The final section will review the extant research on retention in online courses.

\section{B. Tinto's Model}

Tinto [6,9] developed and tested a theory of student departure that has been studied, affirmed, and adjusted by numerous researchers [e. g. 10, 11, 12, 13]. It is based on "student-institution 'fit'” [14, p. 3] and focuses on two processes of integration into the college or university: academic integration and social integration. Academic integration is affected by the student's academic performance and his/her interactions with faculty and staff, and social integration is affected by the student's involvement with extracurricular activities and peer-group interactions. Certainly, other variables are important for adolescents, such as "pre-entry attributes" (family background, skills and abilities, and prior schooling) and "goals and commitments" (intentions), and the latter do change during college. However, it is not clear whether and to what extent these same variables may be influential in encouraging adults to stay in their educational programs. The model is reproduced in Figure 1. 


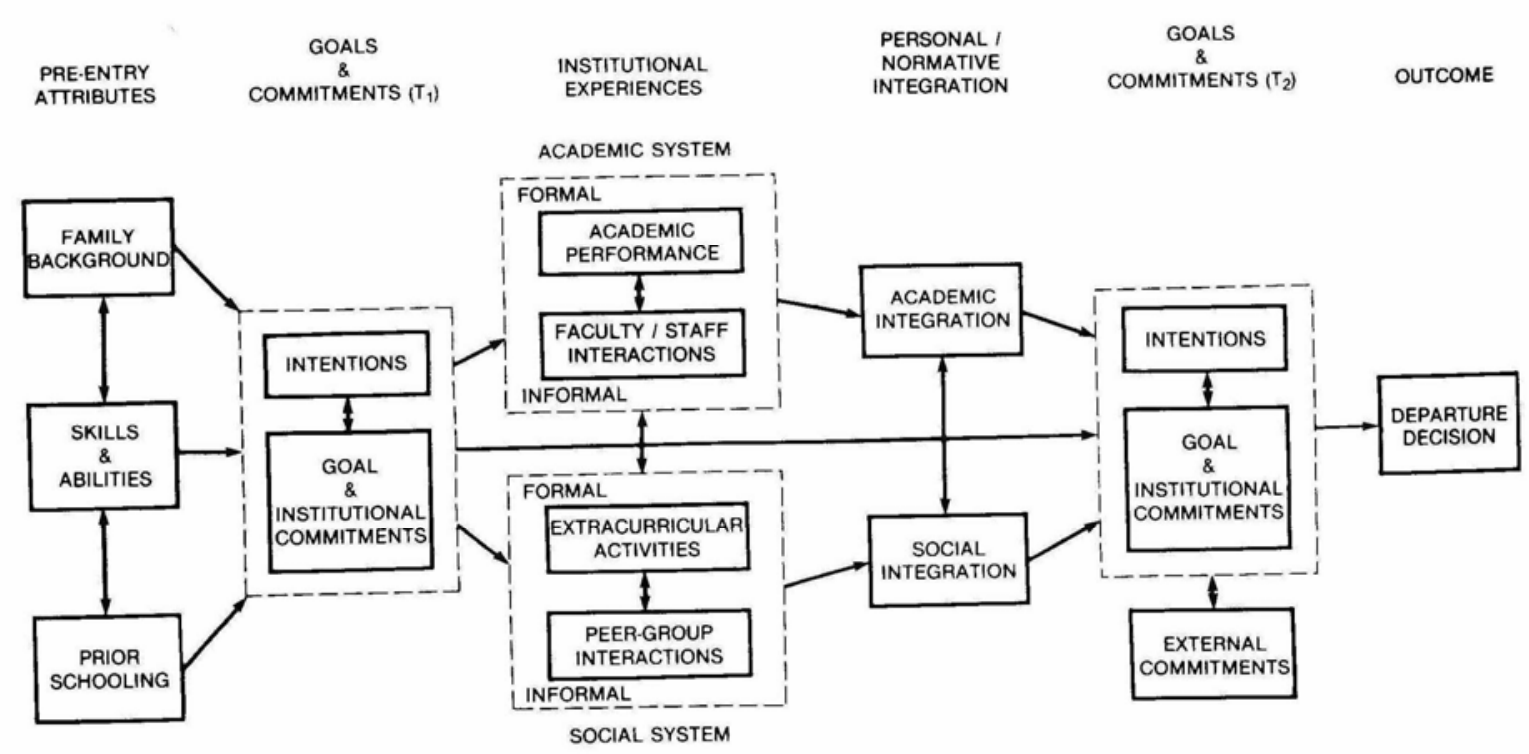

Figure 1. Tinto's (1987) Model of Institutional Departure [6, p. 114]

As a result of research on this model, Tinto [9] concludes that "involvement matters" (p. 167). The more involved students are in the academic and social realms, the more likely they are to persist. And the more they see "those interactions as positive and themselves as integrated into the institution" [9, p. 167], the more likely they will persist. However, integration is less important for students at two-year colleges, who-perhaps because these are more likely to be adults and/or working - may find their validation and social lives elsewhere $[17,18]$. While adults still may value integration and interacting with peers and faculty, but the extent to which this factor may influence retention may be less than it is for adolescents. Thus, the Tinto Model has been found to be especially helpful in explaining departure of traditional-age students and especially those at four-year colleges, but has been less effective in explaining the departure of adult students or those at two-year colleges. One advantage of the Tinto model, however, is the importance placed on ways institutions can actively affect student integration. Its success has been partially responsible for the creation of learning communities and Freshman Interest Groups (FIGs) at colleges and universities [14].

The Tinto model may not be completely appropriate for explaining the retention of the adult students in the online certification program that is the focus of this study. However, given that this model can be characterized as the original if not most widely accepted model for attrition, it is necessary to begin our examination of student retention with it.

\section{Bean and Metzner}

The second theory of attrition is identified with the work of Bean and Metzner [7, 19]. Bean and Metzner studied nontraditional student attrition, more specifically adults over the age of 24 who may be working full-time and other nontraditional students. Their findings are in contrast to Tinto's and describe a student that is less influenced by social integration, places greater influence on the utility of the education being received, as well as greater influence on encouragement from friends, employers, and family. Academic integration—success in learning and interaction with faculty and staff-is also influential, as is finding enough time and finances to support the student's educational pursuits [14]. In fact, even if academic 
integration is positive but environmental factors (such as insufficient time or money) are negative, the positive effects of academic integration are "suppressed or attenuated” [20, p. 29].

These modifications to Tinto's theory make imminent sense: adults are more likely to be pursuing postsecondary education to train for a new job or to gain sufficient skills for professional advancement. They are perhaps more focused on achieving their goals (e.g., finishing the program, gaining the skills needed), and learning is therefore more important than the social aspects of college. For example, when classes are professional and more homogeneous, the experience is more socially integrated with like-minded students studying and supporting each other in the same field [21]. In fact, many of their social friendships are already in place through their jobs, neighborhoods, and families, and these friendships matter in terms of providing encouragement for enrolling and sticking with their college coursework. These insights were confirmed by Grosset [22], whose study of community college students found that integration was more important to younger students (17-24) than older students (25+), study skills (essential to academic success) were the most important predictor of attrition for older students, and cognitive and personal development as well as goal commitment was important for persistence for all groups.

One might expect that the Bean and Metzner model would be more influential in explaining the behavior of the students in our online certification program. These students are adults, and they were pursuing certification in an area that would lead to (or retain) employment as library media specialists in K-12 schools.

\section{Community of Inquiry}

This theory has been developed by Garrison, Anderson, and Archer [8] and it combines three constructs "social presence," "teaching presence," and "cognitive presence"-into a Community of Inquiry model of online learning (see Figure B). Be aware that it is not a retention model per se, but a learning model that has been specifically developed with computer conferencing or online learning in mind. In fact, its concepts of cognitive and social presence may be useful analogs for social and academic integration (terms used by Tinto), although this bears further testing and analysis.

Social presence is the ability of students and faculty to "project themselves socially and emotionally" [8, p. 94]. Teaching presence is the "binding element" [8, p. 96] to creating the Community of Inquiry, and includes developing, managing, and facilitating higher-order learning. "Cognitive presence" is the process of knowledge construction or critical thinking, and moves from perceiving through exploration to integration to resolution. This study will focus specifically on teaching and social presence; the components of each will be detailed in the section on Instrument Development. 


\section{Community of Inquiry}

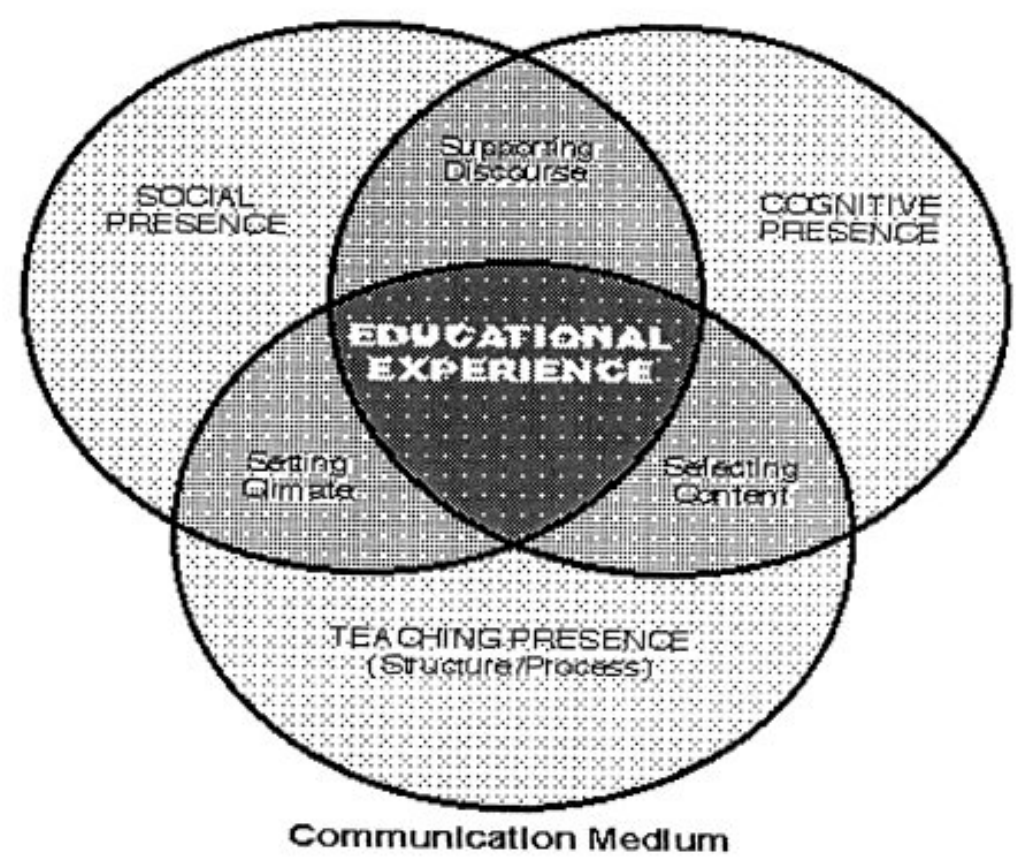

Figure 2: Community of Inquiry Model [24, p. 2]

This model has been researched by a number of authors [23, 24, 25, 26, 27, 28, 29, and 30] who have found support for its various concepts of "presence.” But perhaps its greatest advantage for the present study is its development and use for online education. Perhaps its unique contribution is a specific construct capturing the teachers' specific role-or "teaching presence"-especially in the online setting. This research will focus on two elements of this model, teaching and social presence.

\section{E. Research on Online Retention}

Initially, the attraction of online learning has been its convenience to students who do not have access to desired educational programs in their community. And while the fact that a program is online may be necessary to draw students to it, is it sufficient to keep them enrolled in the program and complete it?

Several studies have focused on students who drop out of online programs. Willging and Johnson [31] specifically looked at dropouts from an online master's program, but found there was not a significant or dominant reason for dropping out and the reasons given were much like the reasons for dropping out of face-to-face programs. In fact, because most reasons given for dropping out were personal (e.g., family problems, job changed), the authors conclude that programs with technology, lack of human interaction, and other problems unique to the online learning environment were not the primary reasons the students left the program. Terry [32] performed similar research on an online MBA and found that while online courses garnered higher enrollments, several topics (e.g., accounting, business statistics) also had higher attrition than on-campus courses. Jones et al. [33] like [30] found that dropping out was caused by technical problems as well as time demands caused by work and other obligations. Diaz [34] concludes that many online students "who drop a class may do so because it is the 'right thing' to do. In other words, because of the requirements of school, work, and/or family life in general, students can benefit more from a class if they take it when they have enough time to apply themselves to the classwork . . . they may be making a mature, well-informed decision.” 
Workman and Stenard [35] identified five needs specific to online students that would help them stay enrolled. Two of these are pertinent to this study: immediate response from faculty or program representatives when prospective students inquire by email about the program and ready access to student services. While addressing these needs are clearly important, so is building an instructional environment that provides self-direction, negotiated work assignments, and interaction through discussion boards with other students in the online class [14]. Informal interactions among students can also be facilitated by online coursework and lessen isolation and increase interaction among students [15]; in fact, frequency of participation in online coursework was a significant predictor of whether students would withdraw or complete the course, as well as their final grade [16]. Therefore, quick response from faculty, student services, opportunities to interact informally and frequently should be course design decisions that are important to include in the study.

So far, these studies do not make a conclusive case that retention is an entirely different phenomenon in the online setting. While online students clearly need computer skills and be able to write and read capably in the online setting, these are increasingly skills that all college students need to be successful in the current higher education setting. Therefore, perhaps the factors that lead to retention are nearly the same for both settings. While this is not a research question for the present study, it is a worthwhile question for other researchers.

\section{METHODOLOGY}

\section{A. The Program}

The online certification program in library media offered by Montana State University (MSU) prepares library media personnel for K-12 schools. By September 2005, the program had enrolled a total of 62 students, 22 of whom had graduated and secured the endorsement or certification credential. The certificate is not a cohort program, and students can begin taking classes in any sequence they wish. Because the program is online and totally asynchronous, it is not surprising to find that this population of students came from 15 states and five nations. Interest in the program can be partially explained by requirements by states and No Child Left Behind legislation for individuals working in K-12 schools to be certified and/or "highly-qualified." Also, due in part to budget cuts in higher education over the past several years, several library science programs had been eliminated at higher education institutions in the western United States.

At the time the planning for this online certification program began (Fall 2000), individuals desiring training in library media could attend a number of graduate programs in library media science. However, these programs required that students come to campus or other sites. In addition, these programs usually required students to earn an entire degree when $\mathrm{K}-12$ teachers (the likeliest audience for this type of training) already had a bachelor's degree and many had a master's degree as well. Several state departments of education were consulted because they govern certification requirements for K-12 personnel; these departments indicated a preference for the program to be at the graduate level due to NCLB and salary schedules. In response to these needs, MSU developed a graduate-level certification program in library media targeted to an audience of (a) certified teachers who wanted to acquire library media certification and (b) practicing school library media specialists who needed to complete their certification.

The program began operation in Summer 2001; one or two courses are offered in fall and spring semesters, with three or four courses offered summer semester. Students are expected to enroll in one or two courses per term and can therefore finish in $1 \frac{1}{2}$ years if they maintain continuous enrollment. While a 
Why They Stayed: Near-Perfect Retention in an Online Certification Program in Library Media

few students have taken a break due to financial, family, or work factors, they return in a semester or two. Only two students have indicated they will not return to the program.

\section{B. Instrument Development}

The instrument used for this study was developed to answer some specific questions of the funding agency and Montana State University. Five questions collected basic demographic data from the respondents, including gender, age, state/country of residence, and current job description. The literature does not indicate whether these variables are crucial to retention, but the information was gathered in order to ascertain if the sample of respondents was in any way different from the population of all current and former students. Two questions were open-ended and requested respondents to provide their top five reasons for a) enrolling in the program (to ascertain motivation) and b) staying enrolled in the program (to ascertain reasons for retention); open-ended questions were used because they would tap into the respondents' personal reasons for enrolling and staying enrolled, rather than artificially narrowing their responses as they selected from those supplied by an instrument.

Sixteen questions were Likert-style items and asked respondents how important a particular factor was in the decision to stay enrolled in the program, where 1=not important, 2=somewhat important, 3 =moderately important, 4=more important, and 5= very important. The list of items included issues of interest to MSU ("The program was offered by MSU" and "Program cost"), issues of interest to online educators ("The program was online" and "Registration and library support was online"). Also included were questions intended to assess Tinto's social integration ("I enjoyed the other students" and "These students are my peers") and academic integration ("I'm fascinated by library media" and "Advising was helpful"). Several questions were intended to capture needs of adult learners from Bean and Metzner's model (e.g., "I didn't have to commute to campus" and "I was treated like an adult"). Several of these questions assessed motivation for enrolling in the program and could be used to triangulate responses to the open-ended question on motivation mentioned earlier.

In the second half of the survey, respondents were asked to assess the faculty in the program. An openended question asked the respondents to provide five examples of what faculty did well. Respondents were asked to assess how well the instructor performed 27 functions in a Likert scale where 1=poorly, $2=$ below average, $3=$ average, $4=$ above average, and 5=very well. These Likert-style items were designed to assess social and teaching presence and were drawn directly from Anderson, Rourke, Garrison, and Archer [18] for teaching presence and Rourke et al. [17] for social presence, with only modest changes to make verb tense consistent. Table 1 identifies which questions assessed which construct within the Community of Inquiry Model.

\begin{tabular}{|l|l|l|}
\hline Question & Presence & Construct \\
\hline 3. Designing activities & Teaching & $\begin{array}{l}\text { Instructional Design and } \\
\text { Organization }\end{array}$ \\
4. Establishing time parameters & & \\
6. Esing media effectively & & \\
\hline 7. Identifying areas of agreement or disagreement & Teaching & Facilitate Discourse \\
8. Seeking to reach consensus or understanding & & \\
9. Encouraging and acknowledging student contributions & & \\
10. Setting a climate for learning & & \\
11. Drawing in participants, prompting discussion & & \\
\hline
\end{tabular}




\begin{tabular}{|l|l|l|}
\hline 12. Assessing efficacy of discussion & & \\
\hline 13. Presenting content and/or questions & Teaching & Direct Instruction \\
14. Focusing discussion on specific issues & & \\
15. Summarizing discussion & & \\
16. Confirming understanding through assessments or & & \\
feedback & & \\
17. Diagnosing misconceptions & & Affective \\
19. Responding to technical concerns & & \\
\hline 20. Responding to questions quickly & Social & \\
21. Using humor & & \\
22. Expressing emotion & & \\
23. Giving me a sense of a real person behind the title & & \\
24. Expressing interest in me as a person & & \\
25. Was friendly and concerned about me. & & \\
\hline
\end{tabular}

Table 1. Survey Questions Linked to Community of Inquiry Model [24, 25]

Please note that this instrument made two changes to the teaching and social presence constructs. Because the instrument needed to be completed within 30 minutes or so, some duplicative items were eliminated and the assessment of social presence focused primarily on the affective dimension, rather than all three dimensions (which includes items assessing interactivity and cohesiveness). This should not diminish the usefulness of these results, especially if by selecting fewer constructs to focus on (and fewer questions to answer), the rate of response was increased.

\section{Procedure and Analysis}

All currently enrolled and graduated students were contacted in early October 2005 by email and their participation in the study requested. Students were directed to a web-based survey instrument hosted by the Western Cooperative for Educational Telecommunications (WCET). The students were given two weeks to complete the instrument, and by October $30,50 \%$ of the targeted students had completed the survey instrument.

Open-ended questions were analyzed by content analysis, looking for consistent and/or inconsistent themes. Once analyzed, answers to the open-ended questions were placed into sensible, consistent groupings and are reported in Tables 3 and 6 by group, with illustrative codings to provide detail and context to reader. Mean responses for each Likert-style item were calculated. Then, questions were grouped as outlined earlier to provide a mean answer for questions based on Tinto's or Bean and Metzner's models; these means were recalculated into a group mean for the various models.

Table 2 provides the demographic data and basic information about the respondents. After a careful comparison to the population of all students and graduates of the program, the sample was deemed representative. Tables 3 through 5 attempt to assess the usefulness of Tinto's and Bean and Metzner's models. To be specific, Table 3 provides a listing of consistent and divergent themes from the open-ended questions on motivation to enroll and stay enrolled; Table 4 provides the mean on each Likert item; and Table 5 presents the group mean for items related to a model. 
Tables 6 through 8 attempt to assess the usefulness of the Community of Inquiry model. To be specific, Table 6 provides a listing of consistent and divergent themes to the open-ended question on what the faculty did well; Table 7 provides the mean on each Likert item; and Table 8 presents the group mean for items related to a Community of Inquiry construct.

\section{FINDINGS}

Table 2 presents demographic information about the sample of respondents to the survey. From this information, we can conclude that the majority of respondents are mid-career, in their 30s and 40s, female, from the west, and already a librarian or media specialist. The majority of respondents had taken several courses in the program. It is interesting, however, how the program was found by individuals as far away as Lithuania and Malaysia without advertising. Note that the individual enrolled from Louisiana had her school severely damaged by Hurricane Katrina.

\begin{tabular}{|c|c|}
\hline Sample & Distribution \\
\hline \multicolumn{2}{|l|}{ Age (in Years) } \\
\hline $20-29$ & -- \\
\hline $30-39$ & 12 \\
\hline $40-49$ & 13 \\
\hline $50-59$ & 5 \\
\hline \multicolumn{2}{|l|}{ Gender } \\
\hline Male & 2 \\
\hline Female & 28 \\
\hline \multicolumn{2}{|l|}{ State/Country of Residence } \\
\hline Alaska & 7 \\
\hline Connecticut & 1 \\
\hline Idaho & 1 \\
\hline Louisiana & 1 \\
\hline Montana & 8 \\
\hline New Hampshire & 1 \\
\hline South Dakota & 4 \\
\hline Tennessee & 2 \\
\hline Washington State & 1 \\
\hline Czechoslovakia & 1 \\
\hline Germany & 1 \\
\hline Lithuania & 1 \\
\hline Malaysia & 1 \\
\hline \multicolumn{2}{|l|}{ Current Occupation } \\
\hline Teacher & 9 \\
\hline Librarian/media specialist & 18 \\
\hline Other (counselor, psychologist, etc.) & 3 \\
\hline
\end{tabular}

Table 2. Student Demographic Data $(n=30)$ 
Table 3 presents the groupings of coded responses to the open-ended questions on what motivated the students to enroll and to stay enrolled. These results provide some support for the assertion that online programs are attractive due to their flexibility and convenience as a result of their being accessible online. Another attraction to this population was specific training in library and media, which provides some support for the assertion that working adults are looking for and attracted to opportunities that will help them in their jobs. Affordability, early interactions with the faculty responsible for recruitment and answering inquiries by potential students, acceptability of the program to local credentialing agencies such as departments of education, and the reputation of MSU were also frequent mentions.

What is interesting, however, is how the reasons for enrolling change somewhat when the question is what keeps the student enrolled. Flexibility and convenience and job-related training remain important, although these receive fewer mentions. What keeps these students enrolled are various qualities of the faculty, the quality of the coursework, and personal reasons. Perhaps one can tentatively conclude that while it is the online nature of the program that lures a student to enroll (and allows them to stay enrolled), it is the nature of the relationships with faculty, the quality of the educational experience, and their own personal and individual reasons and motivations that keep them enrolled. This is perhaps partial support for the academic integration portion of Tinto's model.

\begin{tabular}{|l|l|l|}
\hline Theme & $\begin{array}{l}\text { Motivation } \\
\text { to Enroll }\end{array}$ & $\begin{array}{l}\text { Remain } \\
\text { Enrolled }\end{array}$ \\
\hline $\begin{array}{l}\text { Flexibility/convenience (e.g., online, no commuting, flexible start, ease of } \\
\text { enrollment, can finish in 1 1/2 years, technology easy) }\end{array}$ & 46 & 26 \\
\hline $\begin{array}{l}\text { Job-related training (e.g., needed certification or endorsement, required to } \\
\text { prepare for job, professional growth) }\end{array}$ & 26 & 18 \\
\hline Affordability (e.g., tuition, cost) & 11 & 7 \\
\hline Faculty (e.g., helpful, responsive to questions) & 11 & 19 \\
\hline $\begin{array}{l}\text { Acceptability of program (e.g., accredited by ALA, state’s education dept. } \\
\text { accepts credits) }\end{array}$ & 8 & 2 \\
\hline Reputation of Montana State & 7 & -- \\
\hline Quality of program (e.g., challenging, well-organized, up-to-date) & -- & 14 \\
\hline $\begin{array}{l}\text { Personal (e.g., finish what I start, enjoyable, healthy atmosphere, enjoyed } \\
\text { peers) }\end{array}$ & -- & 19 \\
\hline
\end{tabular}

Table 3. Themes from Open-Ended Question on Motivation to Enroll and Remain Enrolled

NOTE: Respondents were asked for five reasons for why they chose to enroll and remain enrolled, so total responses are greater than the number of respondents.

Table 4 presents the mean response-in order from highest to lowest - to the 16 Likert items on factors that influenced the student to stay enrolled in the program. While all responses are high (most are in the 4.0-4.9 range), it is interesting that the program's availability online was the highest and only consistent response. One might conclude that at least for this group of students, online was a necessary condition for staying enrolled in the program. 


\begin{tabular}{|c|c|c|c|c|c|c|c|}
\hline Item & $\begin{array}{l}\text { Not } \\
\text { Important } \\
(=1)\end{array}$ & $\begin{array}{l}\text { Somewhat } \\
\text { Important } \\
(=2)\end{array}$ & $\begin{array}{l}\text { Moderately } \\
\text { Important } \\
(=3)\end{array}$ & $\begin{array}{l}\text { More } \\
\text { Important } \\
(=4)\end{array}$ & $\begin{array}{l}\text { Very } \\
\text { Important } \\
(=5)\end{array}$ & $\mathbf{N}$ & Mean \\
\hline Program was online & -- & -- & -- & -- & 30 & 30 & 5.0 \\
\hline $\begin{array}{l}\text { I didn't have to commute } \\
\text { to campus }\end{array}$ & -- & -- & -- & 3 & 27 & 30 & 4.9 \\
\hline $\begin{array}{l}\text { Course assignments were } \\
\text { flexible \& help me in my } \\
\text { job }\end{array}$ & -- & -- & -- & 5 & 25 & 30 & 4.8 \\
\hline $\begin{array}{l}\text { Registration \& library } \\
\text { support was online }\end{array}$ & -- & -- & 1 & 6 & 23 & 30 & 4.7 \\
\hline Advising was helpful & -- & -- & 4 & 6 & 20 & 30 & 4.5 \\
\hline I liked the classes & -- & -- & 5 & 5 & 20 & 30 & 4.5 \\
\hline $\begin{array}{l}\text { I'm fascinated by library } \\
\text { media }\end{array}$ & -- & -- & 7 & 7 & 16 & 30 & 4.3 \\
\hline I was treated like an adult & 1 & 2 & 4 & 4 & 19 & 30 & 4.3 \\
\hline $\begin{array}{l}\text { I enjoyed the other } \\
\text { students }\end{array}$ & 2 & 1 & 5 & 7 & 15 & 30 & 4.1 \\
\hline The program cost & 1 & 1 & 9 & 5 & 14 & 30 & 4.0 \\
\hline $\begin{array}{l}\text { I needed certification to } \\
\text { get certified in my state }\end{array}$ & 5 & 1 & 2 & 3 & 19 & 30 & 4.0 \\
\hline $\begin{array}{l}\text { I needed certification to } \\
\text { get a job in library media }\end{array}$ & 5 & 4 & -- & 4 & 17 & 30 & 3.8 \\
\hline $\begin{array}{l}\text { These students are my } \\
\text { peers; I don't have library } \\
\text { media to talk to (in my } \\
\text { job) }\end{array}$ & 3 & 1 & 6 & 12 & 8 & 30 & 3.7 \\
\hline I paid my fees online & 4 & 1 & 8 & 4 & 13 & 30 & 3.7 \\
\hline $\begin{array}{l}\text { Program was offered by } \\
\text { Montana State }\end{array}$ & 5 & 3 & 11 & 3 & 8 & 30 & 3.2 \\
\hline $\begin{array}{l}\text { I needed certification to } \\
\text { stay employed }\end{array}$ & 12 & 2 & 1 & -- & 14 & 29 & 3.1 \\
\hline
\end{tabular}

Table 4. Responses to Likert Questions on the Importance of Factors to Stay Enrolled

(Listed In Order of Mean Response, Highest to Lowest)

Table 5 takes the same responses from Table 4 and groups them into possible indicators of the various retention theories. The first two groups are not retention theories per se, but items to capture issues of interest to MSU and online educators. The next three groups are possible indicators of the social integration portion of Tinto's model, the academic integration portion of Tinto's model, and Bean and Metzner's model for adult, non-traditional students. Please note that these groupings - of items to model - are not intended to be definitive, but suggestive. In any case, these respondents were consistent in their high support for online education as necessary to stay enrolled and moderately supportive of the role of academic integration in keeping them enrolled. Bean and Metzner's model is a close third explanation of why they stayed enrolled, which stresses the importance of job training and more instrumental reasons for staying enrolled. 


\begin{tabular}{|c|c|c|}
\hline Item & Retention Theory or Other Explanation & Group Mean \\
\hline The program cost & \multirow[t]{2}{*}{ Items of interest to Montana State } & \multirow[t]{2}{*}{3.6} \\
\hline Program was offered by MSU & & \\
\hline Program was online & \multirow{3}{*}{ Online as convenience } & \multirow{3}{*}{5.7} \\
\hline Registration \& library support was online & & \\
\hline I paid my fees online & & \\
\hline I enjoyed the other students & \multirow{2}{*}{$\begin{array}{l}\text { Tinto’s social } \\
\text { integration model }\end{array}$} & \multirow[t]{2}{*}{3.9} \\
\hline These students are my peers & & \\
\hline Advising was helpful & \multirow{3}{*}{$\begin{array}{l}\text { Tinto's academic } \\
\text { integration model }\end{array}$} & \multirow{3}{*}{4.4} \\
\hline I'm fascinated by library media & & \\
\hline I liked the classes & & \\
\hline $\begin{array}{l}\text { Course assignments were flexible \& help } \\
\text { me in my job }\end{array}$ & \multirow{6}{*}{$\begin{array}{l}\text { Bean \& Metzner’s } \\
\text { non-traditional adult } \\
\text { retention model }\end{array}$} & \multirow{6}{*}{4.2} \\
\hline I didn’t have to commute to campus & & \\
\hline I was treated like an adult & & \\
\hline $\begin{array}{l}\text { I needed a certification to get a job in } \\
\text { library media }\end{array}$ & & \\
\hline $\begin{array}{l}\text { I needed certification to get certified in } \\
\text { state }\end{array}$ & & \\
\hline I needed certification to stay employed & & \\
\hline
\end{tabular}

Table 5. Group Mean Responses to Likert Questions on Importance of Factors to Stay Enrolled, Categorized by Retention Theory or Other

With Table 6, the analysis focuses on the Community of Inquiry Model and the respondents' assessment of the faculty. What is interesting in the analysis of the open-ended question on what faculty did well is its emphasis on the quality of the course and the faculty's role in designing and carrying out a quality educational experience, and the qualities of the faculty themselves. These qualities are both personal (their passion, helpfulness, and knowledge) and interpersonal (willingness to listen to students and adjust assignments to meet their needs or answer questions and provide feedback). In other words, while the quality of the course takes precedence, the qualities of the faculty are also remarkable and perhaps another key to keeping students enrolled in the program.

\begin{tabular}{|l|l|}
\hline Theme & Distribution \\
\hline $\begin{array}{l}\text { Quality (e.g., up-to-date content, well-designed, practical lessons, clear } \\
\text { expectations, relevant \& thoughtful discussions) }\end{array}$ & 25 \\
\hline Qualities of Faculty (e.g., passionate, wise, helpful, fair, knowledgeable) & 20 \\
\hline $\begin{array}{l}\text { Flexible (e.g., open to suggestions, allowed students to work ahead, } \\
\text { adjust assignments so they are more meaningful to current job) }\end{array}$ & 18 \\
\hline $\begin{array}{l}\text { Responsive (e.g., answered questions, provided feedback, lots of } \\
\text { communication) }\end{array}$ & 17 \\
\hline $\begin{array}{l}\text { Personal (e.g., valued my contributions, treated me professionally, } \\
\text { encouraging) }\end{array}$ & 3 \\
\hline
\end{tabular}

Table 6. Themes from Open-Ended Questions on What Faculty Did Well 
Table 7 presents the mean response-in order from highest to lowest - to the Likert items on questions related to the Community of Inquiry constructs. While again all responses are high (all are in the 4.0-4.8 range), it is interesting that it is the faculty's ability to make themselves "present" or real to the students despite the restrictions of online education that is rated highest.

\begin{tabular}{|c|c|c|c|c|c|c|c|}
\hline Item & $\begin{array}{l}\text { Poor } \\
(=1)\end{array}$ & $\begin{array}{l}\text { Below } \\
\text { Average } \\
(=2)\end{array}$ & $\begin{array}{l}\text { Average } \\
(=3)\end{array}$ & $\begin{array}{l}\text { Above } \\
\text { Average } \\
(=4)\end{array}$ & $\begin{array}{l}\text { Very } \\
\text { Well } \\
(=5)\end{array}$ & $\mathbf{N}$ & Mean \\
\hline $\begin{array}{l}\text { Giving me a sense of a real person } \\
\text { behind the title }\end{array}$ & -- & -- & 1 & 3 & 23 & 27 & 4.80 \\
\hline Setting climate for learning & -- & -- & 2 & 3 & 25 & 30 & 4.77 \\
\hline Establishing netiquette & -- & -- & 2 & 4 & 24 & 30 & 4.73 \\
\hline $\begin{array}{l}\text { Encouraging \& acknowledging student } \\
\text { contributions }\end{array}$ & -- & -- & 2 & 4 & 24 & 30 & 4.73 \\
\hline $\begin{array}{l}\text { Drawing in participants \& prompting } \\
\text { discussion }\end{array}$ & -- & -- & 2 & 4 & 24 & 30 & 4.73 \\
\hline Focusing discussion on specific issues & -- & -- & 1 & 6 & 23 & 30 & 4.73 \\
\hline Injecting knowledge from other sources & -- & -- & -- & 8 & 22 & 30 & 4.73 \\
\hline Presenting content or questions & -- & -- & 2 & 6 & 22 & 30 & 4.67 \\
\hline Responding to questions quickly & -- & -- & 2 & 6 & 22 & 30 & 4.67 \\
\hline Was friendly \& concerned about me & -- & -- & 2 & 6 & 22 & 30 & 4.67 \\
\hline Expressing interest in me as a person & -- & -- & 1 & 8 & 21 & 29 & 4.67 \\
\hline Using media effectively & -- & -- & 1 & 9 & 20 & 30 & 4.63 \\
\hline Establishing time parameters & -- & -- & 2 & 8 & 20 & 30 & 4.60 \\
\hline Using humor & -- & -- & 2 & 8 & 20 & 30 & 4.60 \\
\hline Designing activities & -- & -- & 3 & 7 & 20 & 30 & 4.57 \\
\hline Responding to technical concerns & -- & -- & 4 & 7 & 19 & 30 & 4.50 \\
\hline Expressing emotion & -- & -- & 4 & 7 & 18 & 29 & 4.48 \\
\hline $\begin{array}{l}\text { Identifying areas of agreement or } \\
\text { disagreement }\end{array}$ & -- & -- & 3 & 9 & 16 & 28 & 4.46 \\
\hline $\begin{array}{l}\text { Confirming understanding through } \\
\text { assessments or feedback }\end{array}$ & -- & 1 & 5 & 5 & 18 & 29 & 4.41 \\
\hline $\begin{array}{l}\text { Seeking to reach consensus or } \\
\text { understanding }\end{array}$ & -- & -- & 3 & 12 & 13 & 28 & 4.36 \\
\hline Assessing efficacy of discussion & -- & -- & 6 & 8 & 15 & 29 & 4.31 \\
\hline Summarizing discussion & -- & 2 & 5 & 6 & 16 & 29 & 4.24 \\
\hline Diagnosing misconceptions & -- & 1 & 5 & 9 & 11 & 26 & 4.15 \\
\hline
\end{tabular}

Table 7. Responses to Likert Questions on the Faculty Performance

(Listed In Order of Mean Response, Highest to Lowest)

Table 8 takes the same items in Table 7 and groups them into the constructs in Table 1 and presents a group mean for the construct. While all group means are high, the highest construct is the faculty's "social presence," and more particularly in the affective realm; in other words, these faculty are best at 
projecting themselves socially and emotionally in an online course so that students can get a real sense of them as humans and unique personalities. Also rated highly are the design and organizational skills of the faculty who created the courses and activities that have kept students involved in their learning and perhaps more academically integrated (using Tinto’s term).

\begin{tabular}{|c|c|c|c|}
\hline Question & Presence & Construct & Group Mean \\
\hline $\begin{array}{l}\text { Designing activities } \\
\text { Establishing time parameters } \\
\text { Using media effectively } \\
\text { Establishing netiquette }\end{array}$ & Teaching & $\begin{array}{l}\text { Instructional } \\
\text { Design and } \\
\text { Organization }\end{array}$ & 4.63 \\
\hline $\begin{array}{l}\text { Identifying areas of agreement or disagreement } \\
\text { Seeking to reach consensus or understanding } \\
\text { Encouraging and acknowledging student contributions } \\
\text { Setting a climate for learning } \\
\text { Drawing in participants, prompting discussion } \\
\text { Assessing efficacy of discussion }\end{array}$ & Teaching & $\begin{array}{l}\text { Facilitate } \\
\text { Discourse }\end{array}$ & 4.56 \\
\hline $\begin{array}{l}\text { Presenting content and/or questions } \\
\text { Focusing discussion on specific issues } \\
\text { Summarizing discussion } \\
\text { Confirming understanding through assessments or feedback } \\
\text { Diagnosing misconceptions } \\
\text { Injecting knowledge from other sources } \\
\text { Responding to technical concerns }\end{array}$ & Teaching & $\begin{array}{l}\text { Direct } \\
\text { Instruction }\end{array}$ & 4.50 \\
\hline $\begin{array}{l}\text { Responding to questions quickly } \\
\text { Using humor } \\
\text { Expressing emotion } \\
\text { Giving me a sense of a real person behind the title } \\
\text { Expressing interest in me as a person } \\
\text { Was friendly and concerned about me. }\end{array}$ & Social & Affective & 4.65 \\
\hline
\end{tabular}

Table 8. Group Mean Responses to Likert Questions on the Faculty Performance, Categorized by Community of Inquiry "Presence" and Construct

\section{IMPLICATIONS}

As designed, this study cannot answer certain questions. It cannot answer whether dropouts from an online program might have different assessments of the program and its faculty than those who stay and it cannot answer whether such assessments might be different for students in a traditional program. But the answers we do have are intriguing.

There is support for the importance of academic integration to online learners who stay enrolled. There is also support for adult, non-traditional students to stay enrolled when they are involved with relevant and/or job-related training. But most important, the availability and convenience of online education is necessary to have students like these-working adults without nearby access to the specific programs that will help them prepare or keep their jobs - enroll and stay enrolled. Based on the group mean responses in 
Why They Stayed: Near-Perfect Retention in an Online Certification Program in Library Media

Table 5, Tinto's academic integration and Bean and Metzner's model for adult students are close in importance to these students and graduate, but having the program online is clearly the most important. The portion of Tinto's model devoted to social integration received a lower mean response, which although still high, wasn't as important as academic integration and having their specific adult concerns addressed.

It is tempting, but premature, to assert that the factors that influence a student's decision to stay enrolled in an online program are the same as for other types of programs. In other words, perhaps factors that affect retention do so irrespective of program type. Except, of course, for those students who must have the program online to enroll at all. In other words, perhaps a necessary condition of retention for this population is the program being online, and afterwards, other conditions such as academic integration and relevance to the students' work lives may be sufficient to keep them enrolled.

There is also support for the Community of Inquiry model as a way to distinguish what faculty do well and what students who stay enrolled in an online program find valuable. This use of the model—as a possible explanation for student retention—ought to be explored by other studies.

This study of near-perfect retention has two implications for current and future online programs. First, designers of online programs for adults ought to incorporate content and activities that maximize academic integration and relevance for students. Second, faculty involved with online programs for adults need to learn the techniques for creating teaching and social presence that stress both traditional roles of instruction such as design and facilitating discourse but also ways to let the personality of the instructor come through.

And remember that student from Louisiana? After Hurricane Katrina damaged her school, another student in the certification program worked to have his school district adopt her damaged school. He has been raising supplies and money to help repair the damage to the school and get it ready to open. This is an excellent example of how online education-which draws individuals from several states and countries away-can support learning that is both personally and professionally relevant but also socially important.

\section{REFERENCES}

1. Brigham, D. Benchmark information survey. Unpublished presentation, Excelsior University, 2003.

2. Carr, S. As distance education comes of age, the challenge is keeping the students. The Chronicle of Higher Education: A39-A41, February 11, 2000.

3. Jung, I. and I. Rha. Effectiveness and cost-effectiveness of online education: A review of the literature. Educational Technology 40(4): 57-60, 2000.

4. Roach, R. Staying connected: Getting retention right is high priority for online degree programs. Black Issues in Higher Education: October 24, 2002.

5. Twigg, C. A. Improving quality and reducing cost: Designs for effective learning. Change 35(4): 2329, 2003.

6. Tinto, V. Leaving College: Rethinking the Causes and Cures of Student Attrition. Chicago, IL: University of Chicago Press, 1987.

7. Bean, J. P. and B. S. Metzner. A conceptual model of nontraditional undergraduate student attrition. Review of Educational Research 55(4): 485-540, 1985. 
8. Garrison, D. R., T. Anderson, and W. Archer. Critical inquiry in a text-based environment: Computer conferencing in higher education. The Internet and Higher Education 2(2-3): 87-105, 2000.

9. Tinto, V. Colleges as communities: Taking research on student persistence seriously. Review of Higher Education 21(2): 167-177, 1998.

10. Astin, A. Student involvement: A developmental theory for higher education. Journal of College Student Personnel 25(3): 297-308, 1984.

11. Nora, A. Determinants of retention among Chicano college students. Research in Higher Education, 26(1): 31-59, 1987.

12. Pascarella, E. T. and P. Terenzini. Predicting persistence and voluntary dropout decisions from a theoretical model. Journal of Higher Education 51(1): 60-75, 1980.

13. Terenzini, P. T. and E. T. Pascarella. Voluntary freshman attrition and patterns of social and academic integration in a university: A test of a conceptual model. Research in Higher Education 6(1): 25-43, 1997.

14. Rovai, A. P. In search of higher persistence rates in distance education online programs. The Internet and Higher Education 6: 1-16, 2003.

15. Contreras-Castillo, J., J. Favela, C. Pérez-Fragoso and E. Santamaría-del-Angel. Informal interactions and their implications for online courses. Computers \& Education 42(2): 49-168, 2004.

16. Morris, L. V., C. Finnegan and S. Wu. Tracking student behavior, persistence, and achievement in online courses. The Internet and Higher Education 8(3): 221-231, 2005.

17. Rendon, L. Validating culturally diverse students: Toward a new model of learning and student development. Innovative Higher Education 9(1): 33-52, 1994.

18. Terenzini, P., et al. The transition to college: Diverse students, diverse stories. Research in Higher Education 35(1): 57-73, 1994.

19. Metzner, B. S. and J. P. Bean. The estimation of a conceptual model of nontraditional undergraduate student attrition. Research in Higher Education 27(1): 15-38, 1987.

20. Henry, T. C. and G. P. Smith. Planning student success and persistence: Implementing a statue system strategy. Community College Review 22(2): 26-36, 1993.

21. Ashar, H. and R. Skenes. Can Tinto's student departure model be applied to nontraditional students? Adult Education Quarterly 43: 90-100, 1993.

22. Grosset, J. M. Patterns of integration, commitment, and student characteristics and retention among younger and older students. Research in Higher Education 32(2): 159-178, 1991.

23. Garrison, D. R., T. Anderson and W. Archer. Critical Thinking, Cognitive Presence, and Computer Conferencing in Distance Education. The American Journal of Distance Education 15(1): 7-23, 2001.

24. Anderson, T., L. Rourke, D. R. Garrison and W. Archer. Assessing social presence in asynchronous text-based computer conferencing. Journal of Distance Education 14(2): 2001. http://cade.icaap.org/vol14.2/rourke et al.html.

25. Anderson, T., L. Rourke, D. R. Garrison and W. Archer. Assessing teaching presence in a computer conferencing context. Journal of Asynchronous Learning Networks 5(2): 2001. http://www.sloan-c.org/publications/jaln/v5n2/v5n2 anderson.asp.

26. Wise, A., J. Chang, T. Duffy and R. Del Valle. The effects of teacher social presence on student satisfaction, engagement, and learning. Journal of Educational Computing Research 31(3): 247-271, 2004.

27. Sims, R. and B. Bovard. Interacting with online learners: How new elaborations of online presence can foster critical thinking and reflection. http://www.ascilite.org.au/conferences/perth04/ procs/sims.html.

28. Meyer, K. A. Face-to-Face versus Threaded Discussions: The Role of Time and Higher-Order Thinking. Journal of Asynchronous Learning Networks 7(3): 2003. http://www.sloan-c.org /publications/jaln/v7n3/v7n3_meyer.asp. 
Why They Stayed: Near-Perfect Retention in an Online Certification Program in Library Media

29. Meyer, K. A. Evaluating Online Discussions: Four Frames of Analysis. Journal of Asynchronous Learning Networks 8(2): 2004. http://www.sloan-c.org/publications/jaln/v8n2/v8n2 meyer.asp.

30. Russo, T. and S. Benson. Learning with invisible others: Perceptions of online presence and their relationship to cognitive and affective learning. Educational Technology \& Society 8(1): 54-62, 2005.

31. Willging, P. A. and S. D. Johnson. Factors that influence students' decision to dropout of online courses. Journal of Asynchronous Learning Networks 8(4): 2004 . http://www.sloan-c.org /publications/jaln/v8n4/v8n4_willging.asp.

32. Terry, N. Assessing enrollment and attrition rates for the online MBA. T.H.E. Journal,2001. http://www.thejournal.com/magazine/vault/articleprintversion.cfm?aid=3299.

33. Jones, P., G. Packham, C. Miller and A. Jones. An initial evaluation of student withdrawals within an e-learning environment: The case of e-College Wales. http://www.ejel.org/volume-2/vol2issue1/issue1-art13-jones.pdf.

34. Diaz, D. P. Online drop rates revisited. The Technology Source: May/June 2002. http://technologysource.org/article/online drop rates revisited/.

35. Workman, J. J. and R. A. Stenard. Student support services for distance learners. DEOSNEWS 6(3). Distance Education Online Symposium Website, http://www.ed.psu.edu/acsde/deos /deosnews/deosnews6_3.asp.

\section{ABOUT THE AUTHORS}

Dr. Meyer is currently associate professor of higher and adult education at The University of Memphis specializing in online learning and higher education. She is the author of Quality of Distance Education: Focus on On-Line Learning, a 2002 publication of the ASHE-ERIC Higher Education Report Series. For over three years, she was Director of Distance Learning and Technology for the University and Community College System of Nevada. Prior to this, she served over 8 years as Associate Director of Academic Affairs for the Higher Education Coordinating Board in the state of Washington and was responsible for technology planning and policy related to online learning.

Dr. Bruwelheide is a professor of education in the College of Education, Health, and Human Development at Montana State University-Bozeman. She is the library media program coordinator and project director and principal investigator of the Borderless Access to Training and Education (BATE) grant funded by the U.S. Department of Education FIPSE Learning Anywhere Anytime Partnership (LAAP) program. The grant focused on developing both online educational leadership as well as library media coursework. The BATE-Library Media portion of the grant was approved for continued development through August 2006. Dr. Bruwelheide is recognized nationally for work in distance learning, securing grants, and intellectual property. Her articles, workshops, and book focus on copyright and intellectual property issues as they affect online education.

Russell Poulin is the Associate Director of Western Cooperative for Educational Telecommunications (WCET) (http://www.wcet.info), a membership-based cooperative dedicated to advancing the effective use of technology in higher education. WCET is a unit of the Western Interstate Commission for Higher Education (WICHE). Russ organizes the information-sharing activities among WCET's members and directs EduTools.info, which provides independent reviews of educational software and courses. He also co-directs the Northwest Educational Outreach Network, which uses distance education to expand the reach of programs not available in every WICHE state. Russ also heads the Technology Costing Methodology project, consults on distance education planning projects, and serves on the editorial board of Innovate. 